\title{
Border Disease Control Checkpoints: Are They Sufficient for Disease Control? The Present Situation in Thailand
}

\author{
Viroj Wiwanitkit ${ }^{12^{*}}$ \\ ${ }^{1}$ Dr DY Patil University, India \\ ${ }^{2}$ Medical Academic Center, Bangkok, Thailand
}

Corresponding Author: Viroj Wiwanitkit, MD, Honroary Professor, Wiwanitkit House, Bangkhae, Bangkok, Thailand. Tel: +66-24132436, Email: wviroj@yahoo.com

Received January 13, 2018; Accepted June 17, 2018; Online Published October 13, 2018

Citation: Wiwanitkit V. Border disease control checkpoints: are they sufficient for disease control? The present situation in Thailand. Int J Travel Med Glob Health. 2019;7(1):38. doi:10.15171/ijtmgh.2019.08.

\section{Dear Editor,}

Disease control at border posts is an important public health activity for the prevention of disease in travel medicine. As noted in the review article by Yazdani et al," "immigration and health" is a complex issue in travel medicine and needs special attention. Basically, the importation of disease from an endemic area to a new setting is the main cause of diseases emerging in several countries around the world. Therefore, establishing effective disease control checkpoints at international borders is necessary for the control of the importation of unwanted diseases. ${ }^{2}$

Good systems are usually implemented at international airports and seaports. Nevertheless, international border crossings can also easily occur at land border posts with travelers simply crossing land or small rivers/canals. Thailand, a tropical country in Indochina, shares land borders with many Indochinese countries. Some disease control border checkpoints have been implemented at Thailand's land borders. At present, there are 91 official land borders between Thailand and nearby countries; however, there are only 30 disease control border checkpoints. It seems that the number of functional disease control border checkpoints is about only one third the number of overall official international land borders between Thailand and its neighboring countries. There is no doubt that international disease control at land borders is not effective at present. Indeed, there are also other concerns about the already existing disease control border checkpoints. The lack of disease control facilities and limited human resources are common problems.

In addition, there are many unofficial land border crossing points that have no controls and are routes commonly used by migrants from nearby countries to enter into Thailand. This phenomenon has been well demonstrated as the cause of emerging drug-resistant tuberculosis at the border area between Thailand and Myanmar. ${ }^{3}$ Effective and sufficient disease control border checkpoints and strict control of all unofficial border crossings are required. This and similar situations might exist in many developing countries around the world.

\section{Conflict of Interest Disclosures None.}

\section{Ethical Approval}

Not applicable.

\section{Funding/Support}

None.

\section{References}

1. Yazdani F, Rassafiani M, Tune K, et al. Immigration, participation in health services and social occupations: a literature review. Int J Travel Med Glob Health. 2018;6(2):36-47. doi:10.15171/ ijtmgh.2018.09.

2. Ahmad A, Krumkamp R, Richardus JH, Reintjes R. [Prevention and control of infectious diseases with pandemic potential: the EUproject SARSControl]. Gesundheitswesen. 2009;71(6):351-357. doi:10.1055/s-0029-1224103.

3. Kaji A, Thi SS, Smith T, Charunwatthana P, Nosten FH. Challenges in tackling tuberculosis on the Thai-Myanmar border: findings from a qualitative study with health professionals. BMC Health Serv Res. 2015;15:464. doi:10.1186/s12913-015-1129-0. 